\title{
Activation of $\mathrm{AT}_{1}$ angiotensin receptors induces DNA synthesis in a rat intestinal epithelial (RIE-1) cell line
}

\author{
Roger D. SMITH, ${ }^{\star}$ Anthony N. CORPS, Kathryn M. HADFIELD, Tristan J. VAUGHAN $\dagger$ and Kenneth D. BROWN $\ddagger$ \\ Department of Cellular Physiology, The Babraham Institute, Babraham, Cambridge CB2 4AT, U.K.
}

Proliferation of the rat intestinal epithelial cell-line, RIE-1, has previously been shown to be stimulated by certain polypeptide growth factors acting via receptors that possess intrinsic tyrosine kinase activity. In this study, we show that the octapeptide hormone angiotensin II (AII), apparently acting through the $\mathrm{AT}_{1}$ G-protein-coupled receptor, is also a mitogen for RIE-1 cells. Maximal stimulation of DNA synthesis and cellular proliferation occurred at an AII concentration of $10-100 \mathrm{nM}$, with half-maximal stimulation at $1 \mathrm{nM}$. The mitogenic response to AII was completely inhibited by the $\mathrm{AT}_{1}$ angiotensin-receptor antagonist, DuP753, but not by the $\mathrm{AT}_{2}$-receptor antagonist, PD123319. The early signalling responses activated by AII in RIE-1 cells include increased production of inositol phosphates, a transient increase in the intracellular concentration of free calcium, an activation of protein kinase $\mathrm{C}$, and a rapid change in the pattern of cellular protein-tyrosine phosphorylation. These results implicate an activation of the inositol lipid signalling pathway via the $\mathrm{AT}_{1}$ receptor subtype in the AII-stimulated mitogenic response of this normal epithelial cell line.

\section{INTRODUCTION}

The receptors for many polypeptide growth factors possess intrinsic tyrosine kinase activity that is activated by ligand binding and acts as the first step in a signalling network that controls cellular responses to the ligand (see Schlessinger and Ullrich, 1992; Pazin and Williams, 1992). A second important type of plasma membrane-localized receptor has seven hydrophobic membrane-spanning domains, lacks intrinsic enzymic activity, and couples to intracellular effector systems through heterotrimeric GTP-binding proteins (see Dohlman et al., 1991; Simon et al., 1991; Hepler and Gilman, 1992). Many small peptide hormones and certain regulatory peptides, as well as many non-peptide hormones, bind to receptors of this type. In addition to effects on differentiated cell functions, considerable evidence has been obtained which indicates that some of these agents can act as mitogens for various cell types (see Rozengurt, 1986, 1992; Gupta et al., 1992; Pouyssegur and Seuwen, 1992). Although in certain cases the mitogenic response may be caused by the elevation of cellular cyclic AMP levels (Billestrup et al., 1986; Landis et al., 1989; Burton et al., 1991; Ledent et al., 1992), other potent mitogens (e.g. bombesin, substance $P$, endothelin) have little or no direct effect on this signalling pathway. Interestingly, these peptides share a common ability to stimulate the inositol lipid signalling pathway, although a causal relationship between the activation of this pathway and stimulated cell growth has not been established (see Whitman and Cantley, 1988; Rozengurt, 1989, 1992; Moolenaar, 1991).

RIE-1 cells are an epithelial cell line isolated from the small intestine of a 20-day-old rat (Blay and Brown, 1984) using a procedure originally developed by Quaroni et al. (1979). The cells are non-transformed and non-tumorigenic and during early passages have a normal rat chromosome number (Blay and
Brown, 1984; Brown and Blay, 1986). RIE-1 cells are stimulated to proliferate by epidermal growth factor (EGF), insulin-like growth factor-I (IGF-I) and insulin (Blay and Brown, 1985a,b, 1986; Corps and Brown, 1987). In contrast, transforming growth factor- $\beta$ inhibits the proliferation of RIE-1 cells, while plateletderived growth factor has no effect (R. D. Smith, A. N. Corps and K. D. Brown, unpublished work).

Using 'transmodulation' of EGF receptor affinity as a convenient assay (Brown et al., 1984; Sinnett-Smith and Rozengurt, 1985) we have screened a variety of agents, which are known to act through G-protein-coupled receptors, for activity in the RIE1 cell line. Of those agents tested, only the octapeptide hormone angiotensin II (AII) was found to be active in this assay (R. D. Smith and K. D. Brown, unpublished work). Since peptide hormones can act as mitogens (see above), and since AII itself has been reported to induce hypertrophy and/or hyperplasia of vascular smooth muscle cells (Geisterfer et al., 1988; Dubey et al., 1992), cardiac myocytes and fibroblasts (Sadoshima and Izumo, 1993a), and adrenocortical cells (Gill et al., 1977), we have asked several questions about the interaction of AII with RIE-1 cells. First, which class of angiotensin receptor is expressed? Secondly, can AII act as a mitogen for RIE-1 cells, stimulating DNA synthesis and cell proliferation, and, if so, which intracellular signalling pathways might be involved in mediating the mitogenic response?

\section{EXPERIMENTAL}

\section{Materials}

Dulbecco's modified Eagle's medium (DMEM), antibiotics and trypsin were from ICN Biomedicals, and newborn-calf serum was obtained from Northumbria Biologicals or ICN Biomedicals. Phorbol 12-myristate 13-acetate (PMA) was from Sigma, per-

Abbreviations used: All, angiotensin II: DMEM, Dulbecco's modified Eagle's medium; EGF, epidermal growth factor: IGF-I, insulin-like growth factorI; NA, noradrenaline; PMA, phorbol 12-myristate 13-acetate; TFA, trifluoroacetic acid; $\left[\mathrm{Ca}^{2+}\right]_{\mathrm{i}}$ intracellular free $\mathrm{Ca}^{2+}$ concentration; MAP kinase, mitogen-activated protein kinase; DTT, dithiothreitol; Sar, sarcosine; HRP, horseradish peroxidase; $\left[{ }^{3} \mathrm{H}\right] \mathrm{Ins} P_{\mathrm{t}}$, total labelled inositol phosphates; MARCKS, myristoylated alanine-rich c-kinase substrate.

* Present address: Department of Clinical Biochemistry, Addenbrooke's Hospital, Cambridge CB2 2QQ, U.K.

$\dagger$ Present address: Cambridge Antibody Technology Limited, The Science Park, Melbourn, Cambs. SG6 6EJ, U.K.

¥ To whom correspondence should be addressed. 
tussis toxin was from List Biologicals and AII was from Bachem U.K. $\left[\right.$ methyl $\left.-{ }^{3} \mathrm{H}\right]$ Thymidine and $m y o-\left[2-{ }^{3} \mathrm{H}\right]$ inositol were from Amersham International, and $\mathrm{Na}^{125}$ I was from ICN Biomedicals.

EGF was prepared by the method of Savage and Cohen (1972), and was iodinated as described previously (Brown and Blakeley, 1983). AII was iodinated using the soluble lactoperoxidase method (Thorell and Johansson, 1971). Briefly, to $20 \mu \mathrm{l}$ of a $200 \mu \mathrm{M}$ solution of AII in $20 \mathrm{mM}$ Tris $/ \mathrm{HCl}(\mathrm{pH} 8.0)$ were added $10 \mu \mathrm{l}$ of lactoperoxidase solution ( $25 \mathrm{units} / \mathrm{ml}), 2 \mu \mathrm{l}$ of $0.005 \%(\mathrm{v} / \mathrm{v}) \mathrm{H}_{2} \mathrm{O}_{2}$ and $10 \mu \mathrm{l}$ of $\mathrm{Na}^{125} \mathrm{I}(1 \mathrm{mCi})$. The mixture was incubated for $30 \mathrm{~min}$ at room temperature with occasional agitation. An aliquot $(1 \mathrm{ml})$ of $10 \%(\mathrm{v} / \mathrm{v})$ acetonitrile $/ 0.1 \%$ $(\mathrm{v} / \mathrm{v})$ trifluoroacetic acid (TFA) was then added and the mixture was applied to a Sep-Pak $\mathrm{C}_{18}$ cartridge (Waters). Following elution of free iodide from the cartridge with $10 \%(\mathrm{v} / \mathrm{v})$ acetonitrile $/ 0.1 \%$ (v/v) TFA, ${ }^{125}$ I-AII was eluted with $80 \%$ (v/v) acetonitrile/0.1\% (v/v) TFA. The organic phase was evaporated under a stream of $\mathrm{N}_{2}$ with gentle warming. The residual aqueous phase was diluted with DMEM/0.1\% (w/v) BSA to give a final AII concentration of $1 \mu \mathrm{M}$, and stored in aliquots at $-20^{\circ} \mathrm{C}$. The specific radioactivity of the preparation was $400-550$ c.p.m./fmol in six iodinations. H.p.l.c. analysis revealed a single major peak of activity (results not shown) and the iodinated peptide, which retained full biological activity, was used without further purification.

\section{Cell culture}

Stock cultures of RIE-1 cells were maintained and passaged in DMEM containing 5\% (v/v) newborn-calf serum as described (Blay and Brown, 1984). Most of the experiments were performed using cells between passages 8 and 20. For experimental use, cells were seeded into 24-well cluster plates or 3.5-cm-diam. dishes (Nunc) and used after 7-12 days when they formed a confluent monolayer. When required, down-regulation of protein kinase $\mathrm{C}$ was achieved by pre-treating the cells with PMA $(300 \mathrm{nM})$ for 3 days. After this treatment, no immunoreactive protein kinase $\mathrm{C}$ was detected on Western blots probed with a monoclonal antibody (clone MC5; Amersham International).

\section{Cell proliferation, DNA synthesis and ligand binding assays}

Cell proliferation in response to added factors was determined using an electronic cell counter (Coulter, model $Z_{\mathrm{BI}}$ ) as described previously (Corps and Brown, 1987). To measure $\left[{ }^{3} \mathrm{H}\right]$ thymidine incorporation, confluent monolayers were rinsed with serum-free DMEM and then incubated in $0.5 \mathrm{ml}$ (cluster plate wells) or $2 \mathrm{ml}$ (3.5 $\mathrm{cm}$-diam. dishes) of this medium containing $\left[{ }^{3} \mathrm{H}\right]$ thymidine $(1 \mu \mathrm{Ci} / \mathrm{ml})$, unlabelled thymidine $(1 \mu \mathrm{M})$ and test agents as required. After approx. $40 \mathrm{~h}$ at $37^{\circ} \mathrm{C},\left[{ }^{3} \mathrm{H}\right]$ thymidine incorporation was determined as described by Brown and Blakeley (1983).

${ }^{125}$ I-EGF binding to the cells were assayed essentially as described previously (Brown et al., 1984). Briefly, RIE-1 cells were incubated with ${ }^{125} \mathrm{I}$-EGF $(0.5 \mathrm{ng} / \mathrm{ml})$ together with the test agent at $37^{\circ} \mathrm{C}$ for $45 \mathrm{~min}$ or $4^{\circ} \mathrm{C}$ for $2 \mathrm{~h}$. After extensive washing at $4{ }^{\circ} \mathrm{C}$, specifically bound ${ }^{125} \mathrm{I}-\mathrm{EGF}$ was expressed as a percentage of control binding.

${ }^{125}$ I-AII binding assays were performed using cells grown in 24-well cluster plates. Cells were washed twice in ice-cold binding medium [PBS (140 mM NaCl, $2.7 \mathrm{mM} \mathrm{KCl}, 0.9 \mathrm{mM} \mathrm{CaCl}_{2}$, $\left.0.5 \mathrm{mM} \mathrm{MgCl}, 8 \mathrm{mM} \mathrm{Na} \mathrm{HPO}_{4}, 1.5 \mathrm{mM} \mathrm{KH}_{2} \mathrm{PO}_{4}, \mathrm{pH} 7.4\right)$ supplemented with $0.1 \%(\mathrm{w} / \mathrm{v}) \mathrm{BSA}$ and $0.1 \mu \mathrm{M} \mathrm{KI}$ before incubation overnight at $4{ }^{\circ} \mathrm{C}$ in binding medium $(0.5 \mathrm{ml} /$ well $)$ containing ${ }^{125}$ I-AII and the required concentration of test agent, as indicated in the individual figure legends. After incubation, unbound radioactivity was removed by washing the cells three times with ice-cold binding medium. The washed cells were harvested in solubilization buffer [ $1 \%$ (v/v) Triton X-100, $10 \%$ (v/v) glycerol, $0.1 \%$ (w/v) BSA, $25 \mathrm{mM}$ Hepes, $\mathrm{pH} 7.5]$, and cell-associated radioactivity was measured using a $\gamma$-counter. Cell numbers were determined using the Coulter counter. Nonspecific ${ }^{125}$ I-AII binding was determined by measuring cellassociated radioactivity in cultures incubated with an excess of unlabelled AII $(10 \mu \mathrm{M})$.

\section{Northern blotting}

An $\mathrm{AT}_{1}$ angiotensin receptor-specific DNA probe was prepared by amplification using the PCR. The upstream oligonucleotide primer (5'-GAATCCAAGATGACTGCC-3') is identical to nucleotides 38-55 of the rat $\mathrm{AT}_{1}$ angiotensin receptor cDNA (Murphy et al., 1991), while the downstream primer (5'TCAGCCAGATGATGATGC-3') corresponds to the reverse complement of nucleotides 446-463. These primers, prepared using a Biosearch 8600 DNA synthesizer, were used to amplify a $425 \mathrm{bp}$ fragment from rat liver genomic DNA. The amplified fragment was purified from a low-melting-point agarose gel and its identity was confirmed by digestion with the restriction enzymes SspI and HaeIII, which both gave results consistent with those predicted from the $\mathrm{AT}_{1}$ receptor cDNA sequence (Murphy et al., 1991). The purified PCR product was radiolabelled with $\left[\alpha{ }^{32} \mathrm{P}\right] \mathrm{dCTP}$ according to the method of Feinberg and Vogelstein (1983). RNA was prepared from RIE-1 or Swiss 3T3 cells according to the method of Chomczynski and Sacchi (1987). The radiolabelled PCR product was used to probe Northern blots of total cellular RNA (10 $\mu \mathrm{g} / \mathrm{lane})$ as described (Taylor et al., 1984; Pascall et al., 1989).

\section{Assays of inositol phosphates and intracellular free $\mathrm{Ca}^{2+}\left(\left[\mathrm{Ca}^{2+}\right]_{1}\right)$}

For the measurement of inositol phosphates, confluent monolayers of RIE-1 cells (grown in 3.5-cm-diam. dishes) were prelabelled for approx. $72 \mathrm{~h}$ by the addition of myo- $\left[{ }^{3} \mathrm{H}\right]$ inositol $(1 \mu \mathrm{Ci} / \mathrm{ml})$ directly to the growth medium. After labelling, cells were rinsed with PBS supplemented with $0.1 \%(\mathrm{w} / \mathrm{v}) \mathrm{BSA}$, and incubated in PBS/BSA for $30 \mathrm{~min}$ at $37^{\circ} \mathrm{C}$. The medium was changed again to PBS/BSA containing $10 \mathrm{mM} \mathrm{LiCl}$ and the required concentration of AII. After a $30 \mathrm{~min}$ incubation at $37^{\circ} \mathrm{C}$, the medium was aspirated and the cells were lysed by the addition of $0.5 \mathrm{ml}$ of ice-cold $15 \%(\mathrm{w} / \mathrm{v})$ trichloroacetic acid. Following a further $30 \mathrm{~min}$ incubation on ice, 'total' ${ }^{3} \mathrm{H}$-labelled inositol phosphates (inositol mono-, bis-, tris- and tetrakisphosphates) were extracted and separated by anion-exchange chromatography as described (Heslop et al., 1986; Blakeley et al., 1989).

$\left[\mathrm{Ca}^{2+}\right]_{\mathrm{i}}$ was assayed by Fura-2 fluorescence fluorimetry, using a Hepes-buffered salts solution with minimal changes in cation composition, particularly $\mathrm{Ca}^{2+}$, from those in DMEM (Corps et al., 1989). Confluent cultures of RIE-1 cells grown on glass coverslips $(22 \mathrm{~mm} \times 11 \mathrm{~mm})$ were loaded with Fura-2 by incubation with $2 \mu \mathrm{M}$ Fura-2 acetoxymethyl ester (Sigma) for $45 \mathrm{~min}$ at $37^{\circ} \mathrm{C}$. The coverslip was rinsed, and then was transferred to a cuvette maintained at $37^{\circ} \mathrm{C}$ and equipped with a magnetic stirrer, in a Perkin-Elmer fluorimeter controlled by a microcomputer. Fura-2 fluorescence was excited alternately at 340 and $380 \mathrm{~nm}$, and the emitted light was collected at $509 \mathrm{~nm}$. The values obtained were corrected for autofluorescence, and the fluorescence ratio was updated on a $3 \mathrm{~s}$ cycle; the ratio was 
converted into $\left[\mathrm{Ca}^{2+}\right]_{\mathrm{i}}$ according to the formula and Fura- $2 / \mathrm{Ca}^{2+}$ dissociation constant given by Grynkiewicz et al. (1985).

\section{Western-blot analysis of cellular phosphotyrosyl proteins}

After stimulation with agonists as described in the individual figure legends, cells were rinsed once in DMEM at $4^{\circ} \mathrm{C}$ to remove extracellular protein and dissolved in $250 \mu \mathrm{l}$ of electrophoresis sample buffer. Samples were transferred to a microfuge tube, boiled for $5 \mathrm{~min}$ and centrifuged for $2 \mathrm{~min}$ at $12000 \mathrm{~g}$. Samples were subjected to SDS/PAGE under reducing conditions using a $7 \%(\mathrm{w} / \mathrm{v})$ polyacrylamide resolving gel and a $4 \%$ $(\mathrm{w} / \mathrm{v})$ polyacrylamide stacking gel. The separated proteins were transferred from the gel to a nitrocellulose sheet by electrotransfer (NovaBlot, LKB) for $1.25 \mathrm{~h}$ at approx. $120 \mathrm{~mA}$ in a buffer containing $39 \mathrm{mM}$ glycine, $48 \mathrm{mM}$ Tris, $0.0375 \%$ (w/v) SDS, and $20 \%(\mathrm{v} / \mathrm{v})$ methanol. Blots were blocked by incubation overnight in a buffer (BTT) containing $50 \mathrm{mM}$ Tris (pH 7.4), $150 \mathrm{mM} \mathrm{NaCl}, 30 \mathrm{mg} / \mathrm{ml} \mathrm{BSA}$ and $0.1 \%$ (v/v) Tween-20. After blocking, the blots were incubated for $1 \mathrm{~h}$ at room temperature in BTT containing $0.2-0.5 \mu \mathrm{g} / \mathrm{ml}$ anti-phosphotyrosine antibody (Py20; ICN), and then washed in ten changes of wash buffer [50 mM Tris (pH 7.4), $150 \mathrm{mM} \mathrm{NaCl}, 0.1 \%$ (v/v) Tween-20] for a total time of approx. $1 \mathrm{~h}$. They were then incubated for $1 \mathrm{~h}$ with a 1:1000 dilution (in BTT) of sheep anti-(mouse Ig)-horseradish peroxidase (HRP) conjugate (Amersham), and then washed as described above for a total of approx. $3 \mathrm{~h}$. Immunoreactive proteins were detected using the enhanced chemiluminescence (ECL) system (Amersham) following the manufacturer's instructions.

In order to investigate phosphorylation of mitogen-activated protein (MAP) kinase (ERK2), quiescent cell cultures (9-cmdiam. dishes) were stimulated with agonists, rinsed with DMEM and then extracted into $2 \mathrm{ml}$ of lysis buffer [ $10 \mathrm{mM}$ Tris ( $\mathrm{pH} 7.6$ ), $50 \mathrm{mM} \mathrm{NaCl}, 5 \mathrm{mM}$ EDTA, $30 \mathrm{mM}$ sodium pyrophosphate, $50 \mathrm{mM} \mathrm{NaF}, 100 \mu \mathrm{M}$ sodium orthovanadate, $1 \mathrm{mM}$ phenylmethanesulphonyl fluoride, $1 \%(\mathrm{v} / \mathrm{v})$ Triton $\mathrm{X}-100$ ] for $15 \mathrm{~min}$ at $4^{\circ} \mathrm{C}$. After centrifugation at $12000 \mathrm{~g}$ for $15 \mathrm{~min}$, a portion of the lysate was diluted with an equal volume of $2 \times$ concentrated electrophoresis sample buffer, boiled for $3 \mathrm{~min}$ and subjected to SDS/PAGE under reducing conditions using a $10 \%(\mathrm{w} / \mathrm{v})$ polyacrylamide resolving gel and a $4 \%(\mathrm{w} / \mathrm{v})$ polyacrylamide stacking gel. Western blotting of separated proteins was performed as described above using a $2 \mathrm{~h}$ incubation with affinitypurified polyclonal anti-ERK2 antibodies (Transduction Laboratories) at a concentration of $0.25 \mu \mathrm{g} / \mathrm{ml}$. Immunoreactive proteins were detected using donkey anti-(rabbit Ig)-HRP conjugate (Amersham; 1:1500 dilution) and the ECL system.

\section{RESULTS}

\section{Expression of $A T_{1}$ angiotensin receptors by RIE-1 cells}

The binding of ${ }^{125} \mathrm{I}$-labelled AII $\left({ }^{125} \mathrm{I}-\mathrm{AII}\right)$ to RIE-1 cells was measured as a function of ${ }^{125} \mathrm{I}-\mathrm{AII}$ concentration. Binding was shown to be specific and saturable (Figure 1). Scatchard analysis of the binding data (Figure 1 inset) indicates a single class of high-affinity sites with a $K_{\mathrm{d}}$ of $4.1 \mathrm{nM}$ and a $B_{\max }$. value of $48 \mathrm{fmol} / 1 \times 10^{6}$ cells (approx. 30000 sites per cell, assuming that one molecule of ${ }^{125}$ I-AII binds per site). In a total of 12 experiments, the mean values for $K_{\mathrm{d}}$ and $B_{\max }$ were $3.8 \pm 1.0 \mathrm{nM}$ and $54000 \pm 13000$ sites per cell. These experiments were performed on cells at various passages between 6 and 28, and no correlation was observed between passage number and binding parameters.

Angiotensin receptors have been classified (Bumpus et al.,
1991 ) into two subtypes $\left(\mathrm{AT}_{1}\right.$ and $\left.\mathrm{AT}_{2}\right)$ based on their relative affinities for peptide agonists, peptide and non-peptide antagonists, and their sensitivity to inactivation by the reducing agent, dithiothreitol (DTT) (Chiu et al., 1990; Timmermans et al., 1991a,b; Smith et al., 1992). Angiotensins I, -II and -III, and the antagonist $\left[\mathrm{Sar}^{1}{ } \mathrm{Ile}^{8}\right]$ AII (where Sar represents sarcosine), inhibited the binding of ${ }^{125}$ I-AII to RIE-1 cells with a rank order of potency $\left[\mathrm{Sar}^{1}, \mathrm{Ile}^{8}\right]$ AII $>$ AII $>$ AIII $>$ AI (Figure 2a). Pretreatment of RIE-1 cells with DTT fully inhibited the specific binding of ${ }^{125} \mathrm{I}$-AII with a half-maximal effect at approx. $0.3 \mathrm{mM}$ (results not shown). DuP753, a selective non-peptide antagonist of the $\mathrm{AT}_{1}$ receptor, maximally inhibited ${ }^{125} \mathrm{I}$-AII binding to RIE-1 cells at a concentration of approx. $1 \mu \mathrm{M}$ (Figure $2 \mathrm{~b}$ ). In contrast, the $\mathrm{AT}_{2}$-selective antagonist PD123319 did not inhibit ${ }^{125}$ I-AII binding except at the highest concentration tested (1 mM) (Figure 2b). Taken together, these results indicate that the RIE-1 cells express the $\mathrm{AT}_{1}$ receptor subtype.

The expression of $\mathrm{AT}_{1}$ receptor mRNA by RIE-1 cells was confirmed by Northern blotting, using an $\mathrm{AT}_{1}$ receptor-specific DNA probe generated from rat liver DNA by PCR. The probe hybridized to an approx. 2.3-kb transcript (Figure 3), consistent with the size of the major $\mathrm{AT}_{1}$ transcript detected in various rat tissues (Murphy et al., 1991). The level of this transcript was not markedly altered in cells which had been treated for 60 min with serum, EGF, insulin or IGF-I (Figure 3). Thus short-term exposure to other RIE-1 cell mitogens appears not to affect the expression of the $\mathrm{AT}_{1}$ receptor. Swiss $3 \mathrm{~T} 3$ cells do not respond to AII in any assay we have tested and, consistent with this lack of activity, we did not detect $\mathrm{AT}_{1}$ receptor mRNA in RNA isolated from these cells (Figure 3).

\section{Angiotensin-stimulated phosphoinositide hydrolysis in RIE-1 cells}

Previous studies have demonstrated that $\mathrm{AT}_{1}$ receptors can couple to polyphosphoinositide hydrolysis, $\mathrm{Ca}^{2+}$ channels, or the

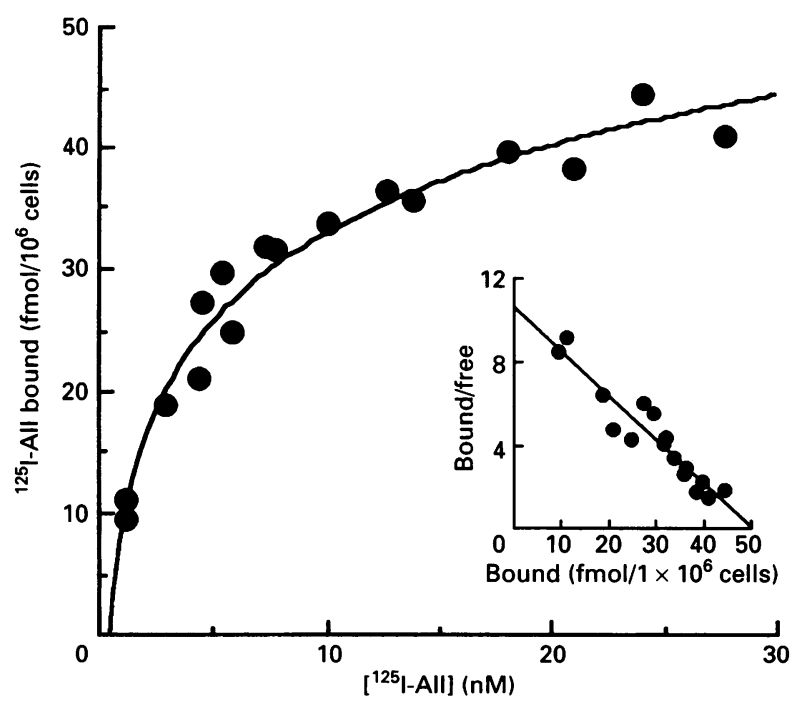

Figure 1 Concentration-dependence of ${ }^{125}$-All binding to RIE-1 cells

Confluent monolayers of RIE- 1 cells were incubated overnight at $4{ }^{\circ} \mathrm{C}$ in the presence of the indicated concentrations of ${ }^{125}$-All, with or without excess unlabelled All $(10 \mu \mathrm{M})$. After removing an aliquot of medium for the determination of the free $\left[{ }^{125} \mid-A l l\right]$, the cells were washed and the bound ${ }^{125} \mathrm{I}$-All was determined as described in the text. The main figure shows the specific binding of ${ }^{125}$-All as a function of concentration. The inset shows a Scatchard plot of the data. Each point represents the value obtained from a single dish of cells. 


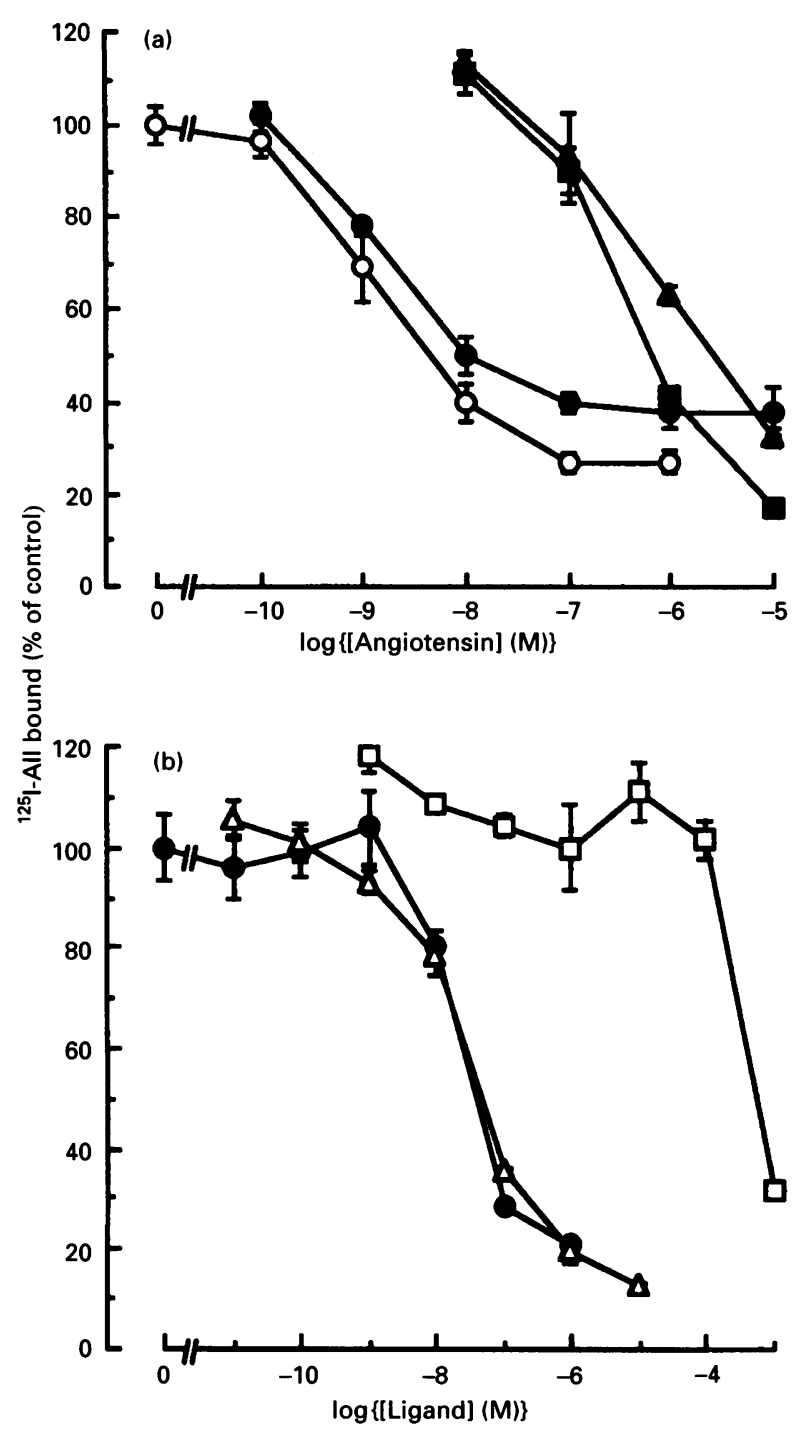

Figure 2 Inhibltion of ${ }^{125}$ I-All binding to RIE-1 cells

Confluent monolayers of RIE-1 cells were incubated overnight at $4^{\circ} \mathrm{C}$ in the presence of ${ }^{125}$ All $(5 \mathrm{nM})$ and unlabelled ligands at the concentrations indicated. The cells were washed and the bound ${ }^{125}$-All was determined as described in the text. In (a) the unlabelled ligands were

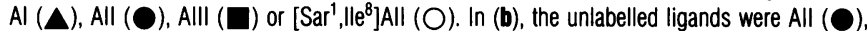
DuP753 $(\triangle)$ or PD123319 ( $\square$ ). Each point represents the mean value ( \pm S.E.M.) from three separate wells.

inhibition of adenylate cyclase (see the Discussion). The effect of AII on the formation of 'total' radiolabelled inositol phosphates $\left(\left[{ }^{3} \mathrm{H}\right] \operatorname{Ins} P_{\mathrm{t}}\right)$ was measured in RIE-1 cells prelabelled by incubation in medium containing $\left[{ }^{3} \mathrm{H}\right]$ inositol. In the presence of $\mathrm{LiCl}$, a 30 min incubation with AII stimulated an increase of up to 22-fold in $\left[{ }^{3} \mathrm{H}\right]$ Ins $P_{\mathrm{t}}$ with a mean maximal increase of 7 -fold in 25 experiments. This stimulation was inhibited by PMA but was not affected by pertussis toxin (results not shown). The dosedependency for the AII-stimulated formation of $\left[{ }^{3} \mathrm{H}\right] \mathrm{Ins} P_{\mathrm{t}}$ is shown in Figure 4(a); a half-maximal response was achieved with an AII concentration of approx. $3 \mathrm{nM}$. The order of potency of different angiotensins in stimulating $\left[{ }^{3} \mathrm{H}\right] \mathrm{Ins} \mathrm{P}_{\mathrm{t}}$ formation was AII $>$ AIII $>$ AI. The antagonist $\left[\operatorname{Sar}^{1}{ }^{1}{ }^{1 l e}{ }^{8}\right]$ AII completely inhibited AII-stimulated $\left[{ }^{3} \mathrm{H}\right] \mathrm{Ins} P_{\mathrm{t}}$ formation (Figure 4b).

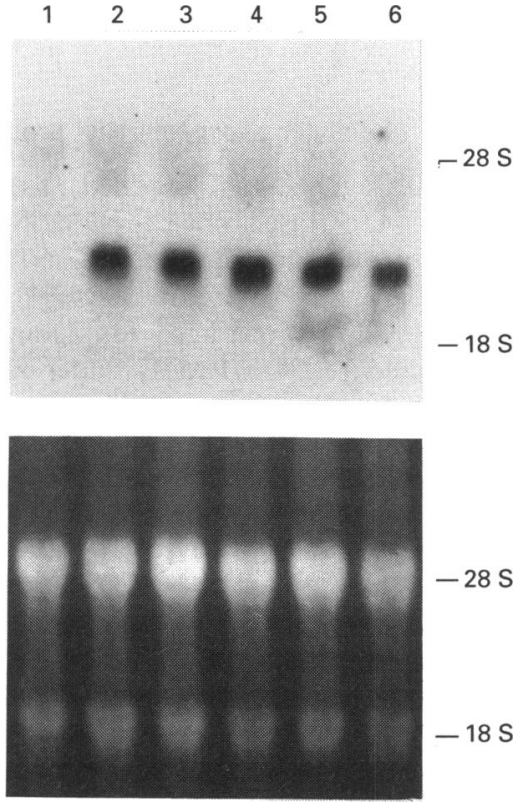
Figure 3 Northern blot of RNA from RIE-1 cells, probed for AT $_{1}$ angiotensin
receptor mRNA

Confluent monolayers of RIE-1 cells in 9-cm-diam. dishes were incubated for $60 \mathrm{~min}$ at $37^{\circ} \mathrm{C}$ in serum-free DMEM, with or without growth factors as indicated below. Total RNA was then isolated, and aliquots were electrophoresed, blotted and probed for $\mathrm{AT}_{1}$ receptor mRNA as described in the text. Lane 1, RNA from Swiss 3 T3 cells, which do not respond to All; lanes $2-6$, RNA from RIE-1 cells treated with vehicle, serum $(10 \%, \mathrm{v} / \mathrm{v})$, EGF $(100 \mathrm{ng} / \mathrm{ml})$, insulin $(1 \mu \mathrm{g} / \mathrm{ml})$ or IGF-I $(100 \mathrm{ng} / \mathrm{ml})$ respectively. The positions of the $28 \mathrm{~S}$ and $18 \mathrm{~S}$ rRNA are shown, and the lower panel shows the ethidium bromide-stained rRNA as an indicator of loading.

\section{Angiotensin activates protein kinase $\mathbf{C}$ in RIE- 1 cells}

Since AII markedly increases phosphoinositide hydrolysis in RIE- 1 cells, we have investigated the ability of the hormone to activate protein kinase $\mathrm{C}$ and raise $\left[\mathrm{Ca}^{2+}\right]_{\mathrm{i}}$ in these cells. Activation of protein kinase $\mathrm{C}$ in a variety of cell types leads to a decreased affinity of the EGF receptor for its ligand (Brown et al., 1984; Sinnett-Smith and Rozengurt, 1985). This temperature-dependent 'transmodulation' of EGF-receptor affinity is thought to be due to the phosphorylation of the receptor by protein kinase $\mathrm{C}$ (see Schlessinger, 1986), although other mechanisms may also be involved (Countaway et al., 1990). Thus an EGF-receptor binding assay provides a means of monitoring in vivo activation of protein kinase C. Angiotensin II was found to significantly inhibit ${ }^{125}$ I-EGF binding when the assay was performed at $37^{\circ} \mathrm{C}$ (Figure 5). In a total of 12 experiments, the mean maximal inhibition was $43 \%$ and maximal responses were obtained with 0.1-1 nM AII. This inhibition of ${ }^{125}$ I-EGF binding was blocked by the presence of $\left[\mathrm{Sar}^{1}, \mathrm{Ile}^{8}\right] \mathrm{AII}$ (results not shown). Consistent with EGF-receptor transmodulation, the effect of AII was markedly temperature-dependent with no inhibition observed when the assay was performed at $4{ }^{\circ} \mathrm{C}$ (Figure 5a). Furthermore, the inhibition was essentially abolished in cells depleted of protein kinase $\mathrm{C}$ by prior incubation with PMA, indicating the involvement of this kinase in the AII-mediated effect (Figure 5b).

\section{Angiotensin-induced $\left[\mathrm{Ca}^{2+}\right]_{1}$ responses in RIE-1 cells}

The effect of AII on $\left[\mathrm{Ca}^{2+}\right]_{\mathrm{i}}$ in RIE-1 cells was measured using the $\mathrm{Ca}^{2+}$-chelating indicator, Fura-2. At a concentration of $100 \mathrm{nM}$, 

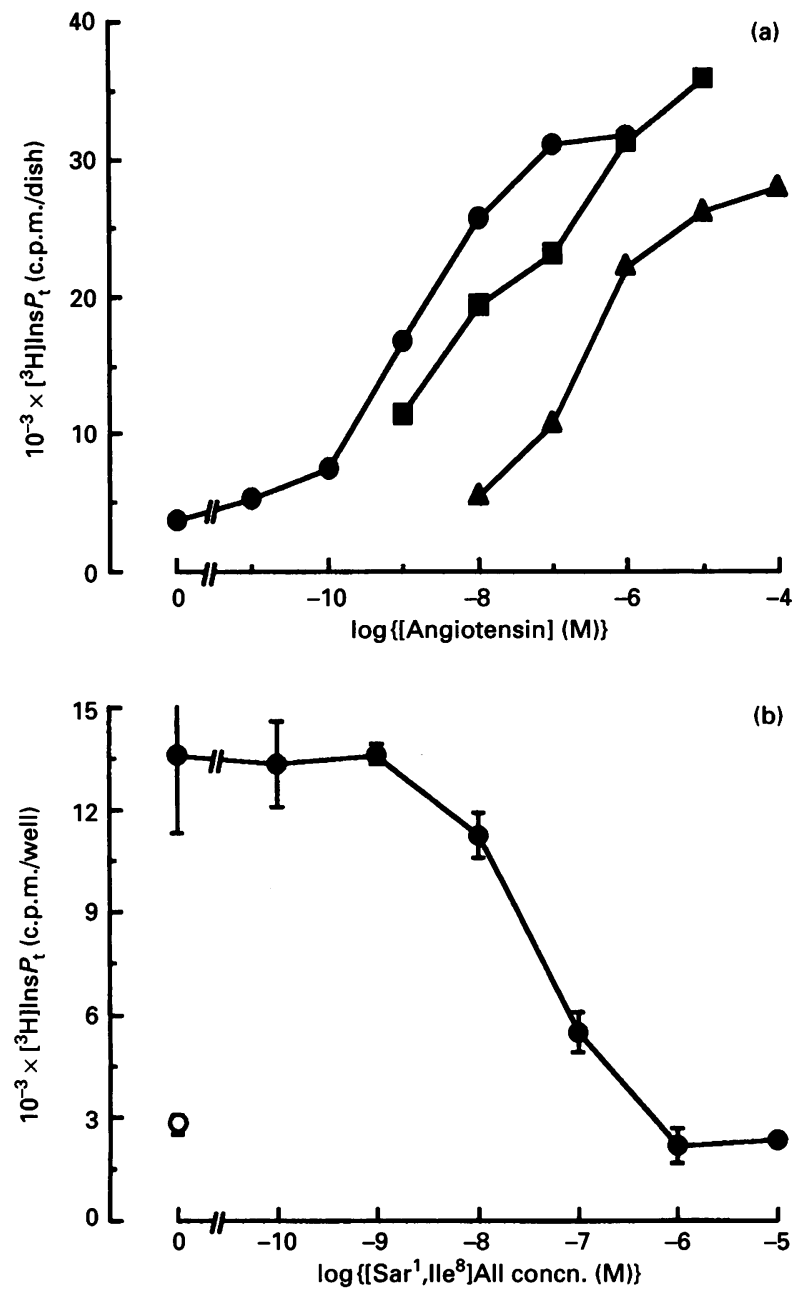

Figure 4 Stimulation of the accumulation of inositol phosphates in RIE-1 cells by angiotensins I, II and III

Confluent monolayers of RIE- 1 cells were prelabelled with $\left[{ }^{3} \mathrm{H}\right]$ inositol as described in the text and treated with angiotensins for $30 \mathrm{~min}$ at $37^{\circ} \mathrm{C}$ in the presence of $\mathrm{LiCl}(10 \mathrm{mM}) .{ }^{3} \mathrm{H}$-labelled 'total' inositol phosphates were then extracted and measured as described in the text. In (a), the ligands used were $\mathrm{Al}(\boldsymbol{\Delta})$, All $(\boldsymbol{O})$, Alll $(\boldsymbol{\square})$ at the concentrations indicated; each point represents the mean value from two separate dishes. In (b), the cells were incubated without (O) or with (O) All (100 nM) in the presence of [Sar, ,lle $]$ All at the concentrations indicated; each point represents the mean value $( \pm$ S.E.M.) from three separate dishes.

AII stimulated a very rapid rise in $\left[\mathrm{Ca}^{2+}\right]_{\mathrm{i}}$ from approx. $90 \mathrm{nM}$ to approx. $750 \mathrm{nM}$ (Figure 6). Peak values of $\left[\mathrm{Ca}^{2+}\right]_{1}$ were reached within $15 \mathrm{~s}$ of peptide addition. Thereafter, $\left[\mathrm{Ca}^{2+}\right]_{\mathrm{i}}$ decreased rapidly reaching approx. $150 \mathrm{nM}$ at $200 \mathrm{~s}$. Lower concentrations of AII induced smaller peak increases in $\left[\mathrm{Ca}^{2+}\right]_{\mathrm{i}}$ as shown in Figure 6. The effects of AII on $\left[\mathrm{Ca}^{2+}\right]_{1}$ in RIE-1 cells were also studied using fluorescence image analysis to monitor changes at a single-cell level. These experiments confirmed the rapid effect of AII on RIE-1 cell $\left[\mathrm{Ca}^{2+}\right]_{1}$, and also indicated that at least $80 \%$ of the cells within the population responded to the peptide (R. D. Smith, K. D. Brown, and T. R. Cheek, unpublished work).

\section{Angiotensin stimulates protein-tyrosine phosphorylation in RIE-1 cells}

Evidence is accumulating that various agonists acting through G-protein-coupled receptors can rapidly induce tyrosine phos-

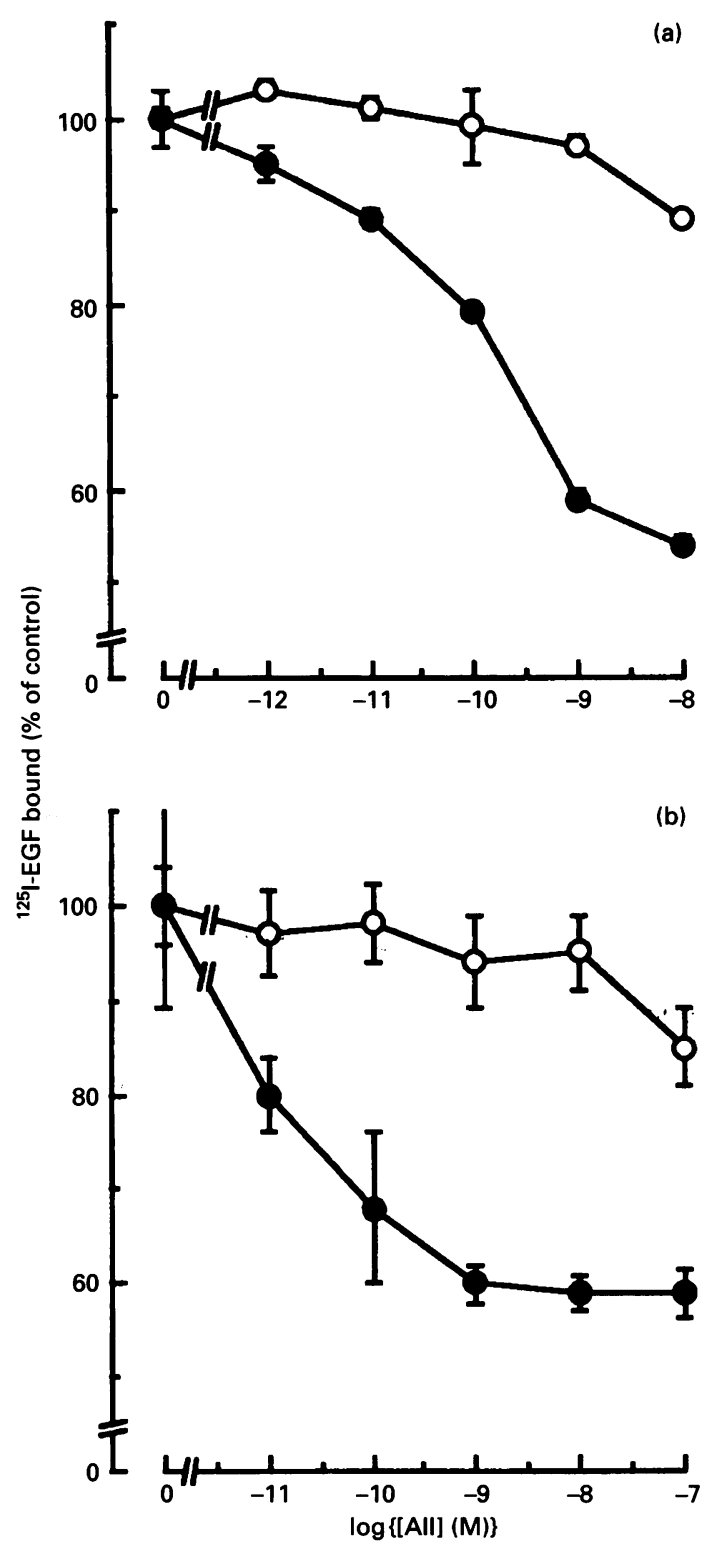

Figure 5 . Temperature- and protein kinase C-dependent inhibition of ${ }^{125}$ EGF binding to RIE-1 cells by All

Confluent monolayers of RIE-1 cells were incubated with ${ }^{125}$-EGF $(0.5 \mathrm{ng} / \mathrm{ml})$ and All at the concentrations indicated, with or without excess unlabelled EGF $(200 \mathrm{ng} / \mathrm{ml})$. In (a), the incubation was performed for $45 \mathrm{~min}$ at $37^{\circ} \mathrm{C}(\mathbf{O})$, or for $2 \mathrm{~h}$ at $4^{\circ} \mathrm{C}(\mathrm{O})$. In (b), control cells $(\mathcal{O})$ and cells that had been pretreated for $72 \mathrm{~h}$ with $300 \mathrm{nM}$ PMA to down-regulate protein kinase $\mathrm{C}(\mathrm{O})$, were incubated with All for $45 \mathrm{~min}$ at $37^{\circ} \mathrm{C}$. In all cases, the specific binding of ${ }^{125}$-EGF was then determined as described in the text, and expressed as a percentage of that in the appropriate control cells. Each point represents the mean value ( \pm S.E.M.) from three separate wells.

phorylation of cellular proteins (see the Discussion). We have therefore tested the ability of AII to stimulate protein-tyrosine phosphorylation in RIE-1 cells by probing Western blots of cell lysates with a monoclonal antibody to phosphotyrosine. Several proteins showed enhanced tyrosine phosphorylation in response to AII. The most prominent increase in labelling was observed in a group of four or five protein bands with molecular masses in the range $65-75 \mathrm{kDa}$ (Figures $7 \mathrm{a}$ and 8). Increased phosphorylation of these proteins was evident by $15 \mathrm{~s}$, the 


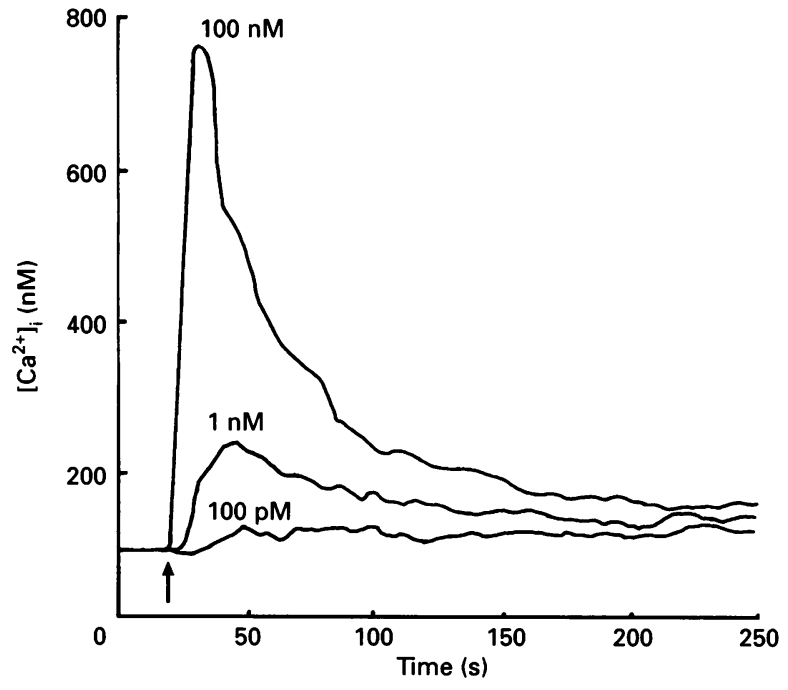

Figure 6 Elevation of $\left[\mathrm{Ca}^{2+}\right]_{1}$ in RIE-1 cells by All

Confluent monolayers of RIE-1 cells grown on glass coverslips were loaded with Fura-2 and incubated at $37^{\circ} \mathrm{C}$ in a fluorimeter cuvette with continuous stirring, as described in the text. At the time indicated (arrow), All was added to give the final concentrations shown. The $\left[\mathrm{Ca}^{2+}\right]_{\text {i }}$ was calculated as described in the text. The recordings shown were obtained on the same day from three separate coverslips of cells from the same passage.

earliest time tested (results not shown). The labelling of the smallest of the protein bands in this group (approx. $65 \mathrm{kDa}$ ) appeared to peak at $0.5 \mathrm{~min}$ and then decreased rapidly, returning to unstimulated levels by $5 \mathrm{~min}$ (Figure 7a). In contrast, labelling of the other proteins in the group remained above basal levels for at least $10 \mathrm{~min}$, the longest time point tested (Figure 7a). The phosphorylation of the 65-75 kDa proteins was also increased in response to EGF, but the response was generally less marked than that induced by AII (Figure 7a). In addition to the increased phosphorylation of the $65-75 \mathrm{kDa}$ proteins, we frequently observed increased labelling of protein bands of approx. 110$130 \mathrm{kDa}$ in response to either AII or EGF (Figure 8). However, the increase in the phosphorylation of these proteins varied considerably between experiments. It is possible that these bands are due to phosphorylation of p125 focal adhesion kinase and p130 (a major phosphotyrosyl protein in $s r c$-transformed cells), since tyrosine phosphorylation of these proteins-is stimulated by mitogenic peptides in Swiss 3T3 cells (Zachary et al., 1992). EGF induced the phosphorylation of several proteins that were not affected by AII; the most prominent of these were at approx. $175,145,57,52$ and $48 \mathrm{kDa}$ (Figure 7a).

In addition to the more prominent bands of tyrosine phosphorylation, both EGF and AII increased the labelling of a protein band at $42 \mathrm{kDa}$ (Figure $7 \mathrm{a}$ ). However, this was a minor band which was clearly detectable by anti-phosphotyrosine Western blotting only in a minority of the experiments performed. We postulated that this band might represent MAP kinase (ERK2), and tested the possibility that this kinase was phosphorylated using the more sensitive method of Western-blot analysis of ERK2 in cell lysates. In response to either EGF or AII, the major ERK2-immunoreactive band in RIE-1 cell lysates was shifted to a lower electrophoretic mobility (Figure 7b), an effect previously correlated with its activation by phosphorylation on both tyrosine and threonine (Leevers and Marshall, 1992; De Vries-Smits et al., 1992). Furthermore, preliminary results (not

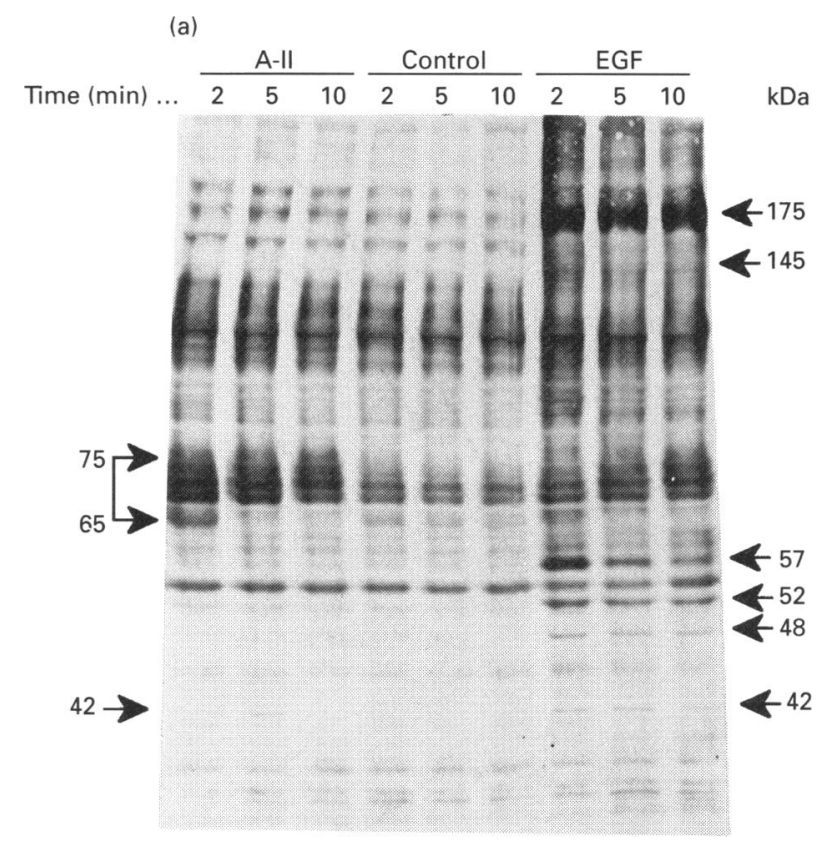

(b)

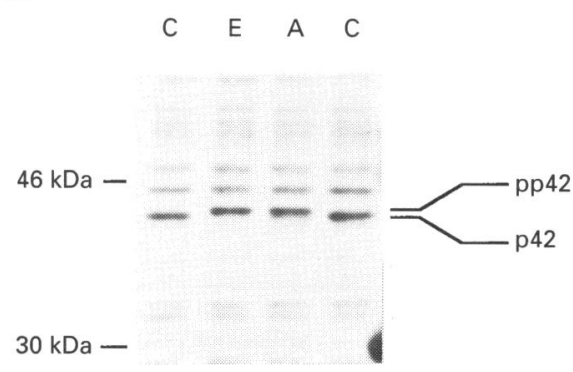

Figure 7 Western blot of protein-tyrosine phosphorylation in RIE-1 cells in response to All or EGF

(a) Confluent monolayers of RIE- 1 cells were incubated at $37^{\circ} \mathrm{C}$ for 2,5 or $10 \mathrm{~min}$ with vehicle All $(1 \mu \mathrm{M})$ or EGF $(200 \mathrm{ng} / \mathrm{ml})$. Extraction of the cells, SDS/PAGE, and Western blotting with an anti-phosphotyrosine antibody were performed as described in the text. The arrows indicate the positions of the main bands showing enhanced phosphorylation. (b) Confluent monolayers of RIE- 1 cells were incubated at $37^{\circ} \mathrm{C}$ for $5 \mathrm{~min}$ with vehicle (C). EGF $(200 \mathrm{ng} / \mathrm{ml}$; E) or All $(1 \mu \mathrm{M} ; \mathrm{A})$. Cell lysis, SDS/PAGE and Western blotting with an anti-ERK2 antibody were performed as described in the text. The positions of the $30 \mathrm{kDa}$ and $46 \mathrm{kDa}$ molecular-mass markers are shown, and the position of the shifted bands is indicated (p42/pp42).

shown) suggest increased levels of immunoreactive ERK2 in anti-phosphotyrosine immunoprecipitates prepared from the same cell lysates. We conclude that AII stimulates the phosphorylation of ERK2 on tyrosine, although further work would be needed to correlate this effect with the $42 \mathrm{kDa}$ band observed on anti-phosphotyrosine Western blots.

AII-induced protein-tyrosine phosphorylation was not affected by pre-incubating the cells overnight in medium containing pertussis toxin at concentrations up to $500 \mathrm{ng} / \mathrm{ml}$, suggesting that the effect is mediated by a pertussis toxin-insensitive pathway (results not shown). However, the increased labelling of the $65-75 \mathrm{kDa}$ proteins induced by incubation for $2 \mathrm{~min}$ with $100 \mathrm{nM}$ AII was fully inhibited by $100 \mu \mathrm{M}$ DuP753 but not by PD123319 (Figure 8), indicating that the response is mediated 


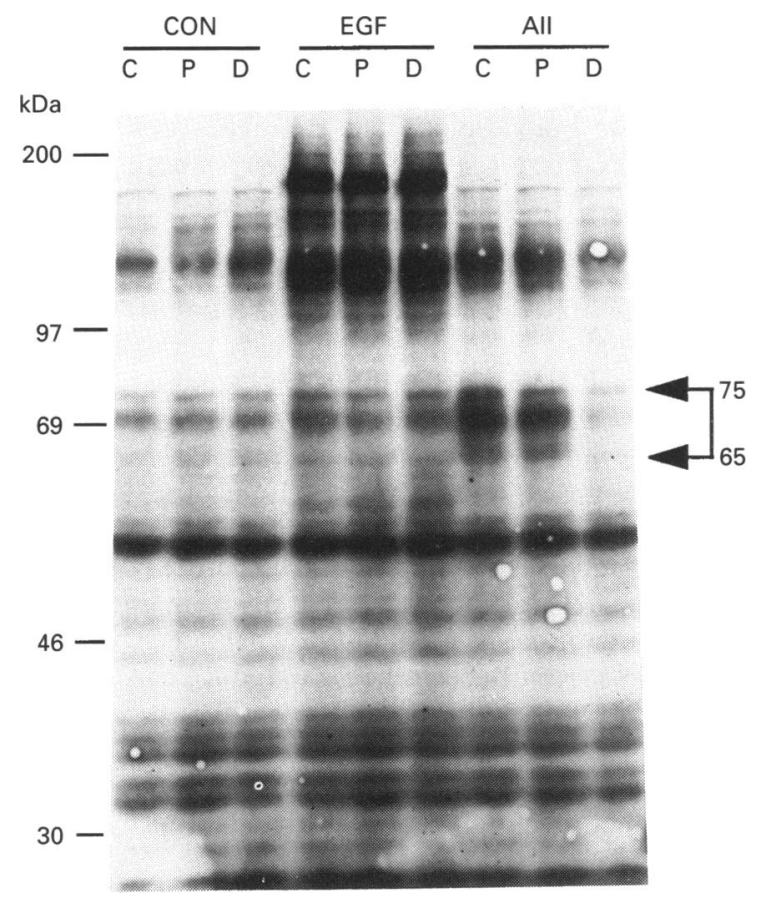

Figure 8 Western blot showing speclific inhibition by DuP753 of Allstimulated protein-tyrosine phosphorylation in RIE-1 cells

Confluent monolayers of RIE-1 cells were incubated for 2 min at $37^{\circ} \mathrm{C}$, with vehicle (CON), All $(1 \mu \mathrm{M})$ or EGF $(200 \mathrm{ng} / \mathrm{ml})$. Some of the cells had been pretreated for 5 min with DuP753 $(100 \mu \mathrm{M}$; D) or PD123319 (100 $\mu \mathrm{M}$; P). Extraction of the cells, SDS/PAGE, and Western blotting with anti-phosphotyrosine antibody were performed as described in the text. The arrows indicate the positions of the main bands showing enhanced phosphorylation.

via the $\mathrm{AT}_{1}$ receptor. Neither antagonist inhibited proteintyrosine phosphorylation in EGF-stimulated cells (Figure 8).

\section{Mitogenic action of All on RIE-1 cells}

In order to test whether AII stimulates DNA synthesis in cultures of RIE-1 cells, the peptide was added to confluent monolayers of cells incubated in serum-free DMEM containing $\left[{ }^{3} \mathrm{H}\right]$ thymidine. AII stimulated a dose-dependent increase in $\left[{ }^{3} \mathrm{H}\right]$ thymidine incorporation by the cells over a concentration range (Figure 9a) which varied slightly between experiments but was similar to that observed for the stimulation of inositol phosphates formation (Figure 4a). The stimulation of $\left[{ }^{3} \mathrm{H}\right]$ thymidine incorporation by AII was fully inhibited by DuP753 but only slightly decreased by PD123319 (Figure 9b), suggesting that AII stimulates DNA synthesis in these cells via the $\mathrm{AT}_{1}$ receptor.

The mitogenic action of AII was also studied by testing the effect of the peptide on RIE-1 cell proliferation. When monolayers of RIE-1 cells, grown in medium containing serum, were given fresh serum-free medium, cell numbers increased over the following 48-72 h (Figure 9c; R. D. Smith and K. D. Brown, unpublished work), presumably due to the replenishment of lowmolecular-mass nutrients and the removal of autocrine inhibitors such as transforming growth factor- $\beta$. However, AII stimulated an additional dose-dependent increase in cell numbers in these cultures, with maximal responses as an AII concentration of approx. $100 \mathrm{nM}$ (Figure 9c). The size of the increase in cell numbers in both control and AII-treated cultures varied between experiments. However, in seven experiments the maximal AIIinduced increase in cell numbers was $141 \pm 29 \%$ (mean \pm S.E.M.) greater than the increase in cell numbers in control cultures, resulting in a final cell number that was $20 \pm 2 \%$ higher in the AII-treated cultures than in control cultures.

\section{DISCUSSION}

Our understanding of the properties and functions of cellular receptors for angiotensin has increased rapidly over the past few years due, in part, to the discovery of powerful non-peptide angiotensin antagonists (see Chiu et al., 1990; Timmermans et al. 1991a,b). Based on the effects of these antagonists, two principal receptor types, designated type $1\left(\mathrm{AT}_{1}\right)$ and type $2\left(\mathrm{AT}_{2}\right)$, have been defined (Bumpus et al., 1991). Binding of angiotensin peptides to the former receptor type is selectively inhibited by DuP753, while binding to the latter is selectively inhibited by PD123177 and PD123319 (Chiu et al., 1990; Dudley et al., 1990). In contrast, angiotensin peptides (agonists and antagonists) show little or no selectivity for these receptor types (Chiu et al., 1990). Some tissues express only one type of receptor, whereas
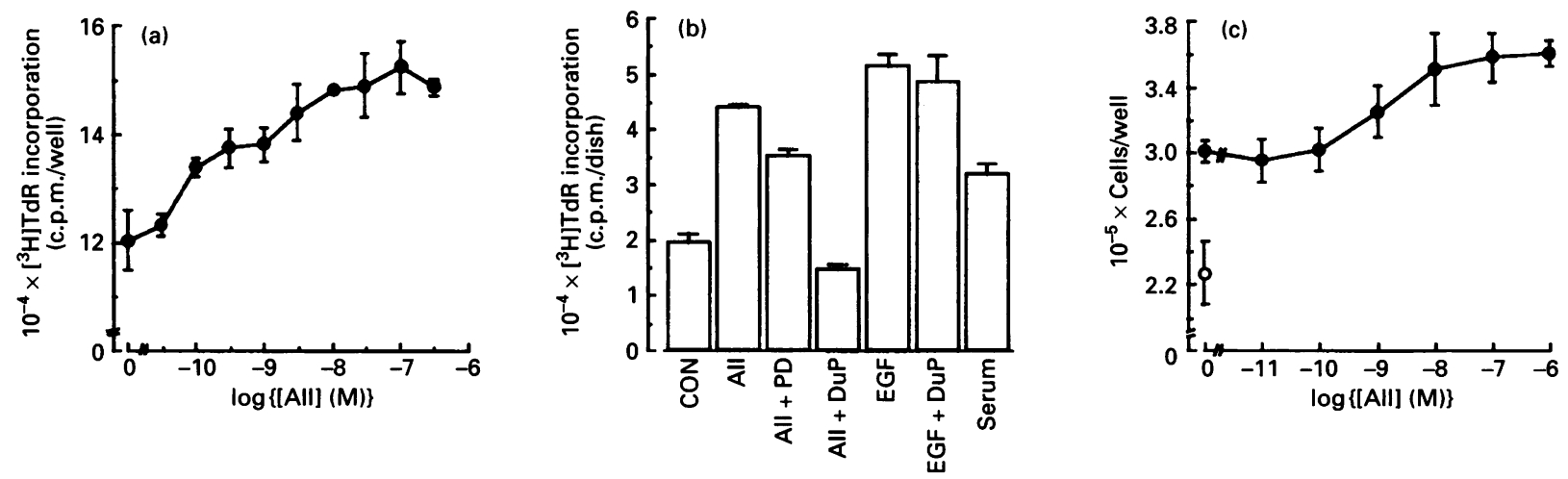

\section{Figure 9 Stimulation of DNA synthesis (a,b) and cell proliferation (c) in RIE-1 cells by All}

Confluent monolayers of RIE-1 cells were incubated at $37^{\circ} \mathrm{C}$ with: $(\mathbf{a}, \mathbf{c})$ the indicated concentration of All; or (b) All $(100 \mathrm{nM}), \mathrm{EGF}(50 \mathrm{ng} / \mathrm{ml})$, DuP753 (100 $\left.\mu \mathrm{M}\right)$, PD123319 (100 $\left.\mu \mathrm{M}\right)$ or serum $(10 \%, v / v)$. Each point represents the mean value ( \pm S.E.M. $)$ from three separate dishes. In $(\mathbf{a})$ and $(\mathbf{b}),\left[{ }^{3} \mathrm{H}\right]$ thymidine was included in the incubation, and the radioactivity incorporated into DNA was determined after $40 \mathrm{~h}$ as described in the text. In $(\mathbf{c})$, cell numbers were determined at the beginning of the incubation $(O)$ and after $72 \mathrm{~h}(\mathbf{O})$; the increase in cell numbers in All-treated cultures was $81 \%$ greater than that which occurred in control cultures over the same period, resulting in a final cell number $20 \%$ higher than in control cultures. 
others express both types (Chiu et al. 1990). In our studies on RIE-1 cells, binding of ${ }^{125}$ I-AII was inhibited by DuP753 to approximately the same extent as was achieved using angiotensin peptides. In contrast, PD123319 did not inhibit binding to the cells, except at very high concentrations. Taken together, these results suggest that RIE-1 cells express only the $\mathrm{AT}_{1}$ type of receptor, although the presence of a very small proportion of $\mathrm{AT}_{2}$ sites cannot be excluded.

The isolation and sequencing of rat, bovine, human and mouse $\mathrm{AT}_{1}$ receptor cDNA clones has recently been reported (see Bernstein and Alexander, 1992; Iwai et al., 1991, 1992). In addition, a second $\mathrm{AT}_{1}$-receptor subtype was cloned from rat adrenal and pituitary cDNA libraries (Iwai and Inagami, 1992; Kakar et al., 1992). The two subtypes $\left(\mathrm{AT}_{1 \mathrm{a}}\right.$ and $\mathrm{AT}_{1 \mathrm{~b}}$ ) are encoded by separate genes and their mRNAs show differential expression and regulation. However, the predicted amino acid sequences show that the receptor subtypes are very closely related members of the seven-membrane-spanning-domain, Gprotein-coupled family of receptors. Furthermore, both receptor subtypes show similar binding properties (Iwai and Inagami, 1992; Kakar et al., 1992) and, when transfected into cells, mediate a rapid increase in $\left[\mathrm{Ca}^{2+}\right]_{\mathrm{i}}$ in response to AII (Murphy et al., 1991; Kakar et al, 1992; Sandberg et al., 1992). The 425-bp $\mathrm{AT}_{1}$ receptor $\mathrm{cDNA}$ which we generated using PCR spans a region in which the nucleotide sequence is highly conserved between the $\mathrm{AT}_{1 \mathrm{a}}$ and $\mathrm{AT}_{1 \mathrm{~b}}$ receptor subtypes. Consequently, we would not expect our probe to discriminate between $\mathrm{AT}_{1 \mathrm{a}}$ and $\mathrm{AT}_{1 \mathrm{~b}}$ mRNA transcripts on Northern blots. However, reverse transcription-PCR amplification using primers designed to selectively amplify $\mathrm{AT}_{1 \mathrm{a}}$ or $\mathrm{AT}_{1 \mathrm{~b}} \mathrm{cDNA}$, suggests that the predominant transcript in RIE-1 cells is the product of the $\mathrm{AT}_{1 \mathrm{a}}$ gene (T. J. Vaughan, unpublished work).

RIE-1 cells have many similarities with the IEC-6 intestinal epithelial cell line derived by Quaroni and co-workers (Quaroni et al., 1979). Like RIE-1 cells, IEC-6 cells display specific binding of ${ }^{125}$ I-AII and are responsive to AII (R. D. Smith, unpublished work). The presence of functionat angiotensin receptors in both these cell lines raises the possibility that such receptors might also be expressed by intestinal epithelial cells in vivo. In support of this possibility, Cox et al. (1986) have reported the presence of high-affinity ${ }^{125}$ I-AII-binding sites on epithelial membranes from rat jejunum and descending colon. In addition, AII was found to exert an apparently direct effect on electrogenic ion transport in intestinal epithelial sheets mounted in Ussing-like chambers (Cox et al., 1987). Autoradiographic studies of ${ }^{125}$ I-labelled $\left[\mathrm{Sar}^{1}, \mathrm{Ile}^{8}\right] \mathrm{AII}$ binding to frozen sections of rat intestine have produced conflicting results. Duggan et al. (1989) observed binding only to the muscularis layer with no apparent binding of the peptide to the mucosa, whereas Sechi et al. (1993) reported moderately abundant binding at both sites. In the latter study, binding of the labelled peptide to both mucosa and muscularis was inhibited by $80-90 \%$ by DuP753, suggesting the presence of $\mathrm{AT}_{1}$ receptors. Additional studies, perhaps using in situ hybridization and/or immunocytochemical staining, will be needed to resolve this question.

A number of investigators have observed trophic effects of AII on various cell types in culture. For example, Gill et al. (1977) reported some years ago that AII stimulates DNA synthesis and proliferation in cultures of bovine adrenal-cortex cells. Because of a potential involvement in the mechanisms of hypertension, the effects of AII on the growth of vascular smooth muscle cells have been studied by several groups. AII has been found to stimulate protein synthesis and hypertrophy of cultured aortic smooth muscle cells without affecting DNA synthesis or cell proliferation (Geisterfer et al., 1988; Berk et al., 1989). AII has also been found to stimulate protein synthesis in cultures of rat and chick heart myocytes (Baker and Aceto, 1990; Sadoshima and Izumo, 1993a). In contrast with these primarily hypertrophic effects, AII has been reported to stimulate proliferation and hyperplasia in cultures of renal arteriolar smooth muscle cells (Dubey et al., 1992) and cardiac fibroblasts (Sadoshima and Izumo, 1993a). Norman et al. (1987) reported that AII potentiated EGF-stimulated DNA synthesis in primary cultures of rabbit kidney proximal tubule cells. Our results using RIE-1 cells indicate that AII, added alone, can have mitogenic effects on an epithelial cell line. Furthermore, the stimulation of DNA synthesis and cell proliferation in RIE-1 cells by AII is comparable in size with that obtained when these cells are stimulated by polypeptide growth factors such as EGF or IGF-I (Blay and Brown, 1985a; Corps and Brown, 1987). To our knowledge, none of the above studies have formally excluded the possibility that the effects of AII are indirect, resulting from the stimulated production and autocrine action of polypeptide growth factors. Indeed, AII has recently been shown to induce heparin-bindingEGF production by smooth muscle cells (Temizer et al., 1992), which are very sensitive to stimulation by this factor (Higashiyama et al., 1991). We are currently investigating the possible production of polypeptide growth factors by RIE-1 cells in response to AII.

Irrespective of whether the trophic effects of AII are direct or indirect, recent studies suggest that they are mediated through the $\mathrm{AT}_{1}$ receptor. AII-stimulated protein synthesis in cardiac myocytes and DNA synthesis in cardiac fibroblasts are blocked by DuP753 (Sadoshima and Izumo, 1993a), and AII-stimulated growth of zona-fasciculata-reticularis cells from bovine adrenalcortex has recently been reported to be mediated by the $\mathrm{AT}_{1}$ receptor (Clyne et al., 1993). In the work presented here, we found that the stimulation of DNA synthesis by AII in RIE-1 cells is fully inhibited by DuP753, indicating that $\mathrm{AT}_{1}$ receptors mediate the mitogenic response.

Pharmacological studies using various tissues have demonstrated that $\mathrm{AT}_{1}$ receptors can couple to at least three different signalling pathways: stimulation of phospholipase $\mathrm{C}$ leading to polyphosphoinositide hydrolysis (Griendling et al., 1986; Spät, 1988; Pfeilschifter et al., 1989), activation of voltage-dependent $\mathrm{Ca}^{2+}$ channels (Hausdorff and Catt, 1988; Hescheler et al., 1988), and inhibition of adenylate cyclase via a pertussis toxin-sensitive G-protein (Pobiner et al., 1985; Balla et al., 1991). We have found that the activation of $\mathrm{AT}_{1}$ receptors on RIE-1 cells causes a substantial stimulation of inositol phosphates formation, a rapid rise in $\left[\mathrm{Ca}^{2+}\right]_{i}$, and a protein kinase $\mathrm{C}$-dependent inhibition of ${ }^{125}$ I-EGF binding. In several cell types, the myristoylated alanine-rich c-kinase substrate (MARCKS) protein is a prominent substrate for protein kinase $\mathrm{C}$, and its phosphorylation has been used as a marker for the activation of this kinase (see Rozengurt, 1989; Blackshear, 1993). We attempted to use the stimulated phosphorylation of the MARCKS protein as further evidence for activation of protein kinase C by AII in RIE-1 cells. However, we found that these cells express little or no MARCKS protein as judged by analysis of ${ }^{32} \mathrm{P}$-labelled phosphoproteins in PMA-treated cells, and by Northern and Western blots of RIE-1 cell extracts. Therefore, protein kinase C-dependent inhibition of ${ }^{125} \mathrm{I}$-EGF binding remains the principal evidence that AII activates this kinase in RIE-1 cells.

In contrast with the large effect of AII on the inositol lipid signalling pathway, our preliminary results (not shown) suggest that the peptide has little effect on cyclic AMP levels in RIE-1 cells: in the presence of isobutylmethylxanthine, AII induced a very small increase in cyclic AMP levels and slightly potentiated the effect of agonists which activate adenylate cyclase. Although 
AII inhibits adenylate cyclase in some cells (Pobiner et al., 1985; Balla et al., 1991), there are other reports of a small AIIstimulated increase in cellular cyclic AMP levels, apparently mediated through the protein kinase $\mathrm{C}$ and calmodulin pathways (Langlois et al., 1992; Sadoshima and Izumo, 1993b).

It has recently become clear that a number of peptide hormones, not known to activate receptor tyrosine kinases, are nevertheless capable of stimulating the rapid tyrosinephosphorylation of cellular proteins (see Zachary and Rozengurt, 1992). Interestingly, AII has been shown to stimulate tyrosine phosphorylation of cellular proteins in WB rat liver epithelial cells (Huckle et al., 1990) and in rat kidney mesangial cells (Force et al., 1991). In our experiments we have observed increased tyrosine phosphorylation of proteins, primarily in the range of approx. $65-75 \mathrm{kDa}$, in AII-stimulated RIE-1 cells. We have demonstrated that this phosphorylation response is rapid, and that it is mediated via the $\mathrm{AT}_{1}$ receptor since it is fully inhibited by DuP753. The mechanisms involved in the stimulation of protein-tyrosine phosphorylation via G-protein-coupled receptors are not clear. In principle, the response could be due to coupling of the receptor to the activation of a tyrosine kinase(s) or the inhibition of a tyrosine phosphatase(s). Alternatively, regulation of a tyrosine kinase or phosphatase could occur downstream of other signals initiated by receptor activation. In this context it should be noted that many of the peptides shown to induce tyrosine phosphorylation of cellular proteins are also known to activate phosphoinositide hydrolysis, as shown for AII in this study. Furthermore, evidence has recently been presented which suggests that $\mathrm{AII}$ activates a $\mathrm{Ca}^{2+}$-dependent cytosolic tyrosine kinase, although the identity of this remains to be established (Huckle et al., 1992).

Our finding that AII stimulates DNA synthesis and proliferation in a non-transformed epithelial cell line supports the view that agonists acting through G-protein-coupled receptors, in addition to their role in regulating differentiated cell function, may also be involved in the regulation of cell proliferation. That such control is physiologically relevant has been most clearly demonstrated in a series of elegant experiments which show how an increase in cyclic AMP mediated by growth-hormonereleasing factor is an important regulator of the growth and development of pituitary somatotrophs [see Montminy (1993) for review]. However, many agonists which act as mitogens in vitro have little, if any, direct effect on cyclic AMP levels. The observation that many of these mitogenic agonists potently stimulate phosphoinositide hydrolysis, together with the knowledge that tumour-promoting phorbol esters act through protein kinase C (see Nishizuka, 1986, 1992), has prompted suggestions that the inositol lipid signalling pathway may be important in cell growth regulation. The results we have presented here shown that RIE-1 cells are mitogenically responsive to AII acting through the G-protein-coupled $\mathrm{AT}_{1}$ receptor, and that the peptide is a powerful stimulator of inositol lipid hydrolysis in these cells. However, additional studies will be needed to establish whether a causal relationship exists between the activation of this signalling pathway and the stimulation of RIE-1 cell DNA synthesis and proliferation.

\section{REFERENCES}

Baker, K. M. and Aceto, J. F. (1990) Am. J. Physiol. 259, H610-H618

Balla, T., Baukal, A. J., Eng, S. and Catt, K. J. (1991) Mol. Pharmacol. 40, 401-406

Berk, B. C., Vekshtein, V., Gordon, H. M. and Tsuda, T. (1989) Hypertension 13, 305-314

Bernstein, K. E. and Alexander, R. W. (1992) Endocr. Rev. 13, 381-386

Billestrup, N., Swanson, L. W. and Vale, W. (1986) Proc. Natl. Acad. Sci. U.S.A. 83, $6854-6857$

Brackshear, P. J. (1993) J. Biol. Chem. 268, 1501-1504
Blakeley, D. M., Corps, A. N. and Brown, K. D. (1989) Biochem. J. 258, 177-185

Blay, J. and Brown, K. D. (1984) Cell Biol. Int. Rep. 8, 551-560

Blay, J. and Brown, K. D. (1985a) Biochem. J. 225, 85-94

Blay, J. and Brown, K. D. (1985b) J. Cell. Physiol. 124, 107-112

Blay, J. and Brown, K. D. (1986) J. Cell. Physiol. 129, 343-346

Brown, K. D. and Blakeley, D. M. (1983) Biochem. J. 212, 465-472

Brown, K. D. and Blay, J. (1986) In Control and Manipulation of Animal Growth (Buttery,

P. J., Haynes, N. B. and Lindsay, D. B., eds.), pp. 119-134, Butterworths, London

Brown, K. D., Blay, J., Irvine, R. F., Heslop, J. P. and Berridge, M. J. (1984) Biochem. Biophys. Res. Commun. 123, 377-384

Bumpus, F. M., Catt, K. J., Chiu, A. T., DeGasparo, M., Goodfriend, T., Husain, A., Peach,

M. J., Taylor, D. G. and Timmermans, P. B. M. W. M. (1991) Hypertension 17, 720-721

Burton, F. H., Hasel, K. W., Bloom, F. E. and Sutcliffe, J. G. (1991) Nature (London) 350 , 74-77

Chiu, A. T., McCall, D. E., Ardecky, R. J., Duncia, J. V., Nguyen, T. T. and Timmermans, P. B. M. W. M. (1990) Receptor 1, 33-40

Chomczynski, P. and Sacchi, N. (1987) Anal. Biochem. 162, 156-159

Clyne, C. D., Nicol, M. R., MacDonald, S., Williams, B. C. and Walter, S. W. (1993) Endocrinology 132, 2206-2212

Corps, A. N. and Brown, K. D. (1987) J. Endocr. 113, 285-290

Corps, A. N., Cheek, T. R., Moreton, R. B., Berridge, M. J. and Brown, K. D. (1989) Cell Reg. 1, 75-86

Countaway, J. L., McQuilken, P., Girones, N. and Davis, R. J. (1990) J. Biol. Chem. 265, $3407-3416$

Cox, H. M., Munday, K. A. and Poat, J. A. (1986) Br. J. Pharmacol. 87, 201-209

Cox, H. M., Cuthbert, A. W. and Munday, K. A. (1987) Br. J. Pharmacol. 90, 393-401

De Vries-Smits, A. M. M., Burgering, B. M. T., Leevers, S. J., Marshall, C. J. and Bos, J. L. (1992) Nature (London) 357, 602-604

Dohlman, H. G., Thorner, J., Caron, M. G. and Lefkowitz, R. J. (1991) Annu. Rev. Biochem. 60, $653-688$

Dubey, R. K., Roy, A. and Overbeck, H. W. (1992) Circ. Res. 71, 1143-1152

Dudley, D. T., Panek, R. L., Major, T. C., Lu, G. H., Bruns, R. F., Klinkefus, B. A., Hodges, J. C. and Weishaar, R. E. (1990) Mol. Pharmacol. 38, 370-377

Duggan, K. A., Mendelsohn, F. A. O. and Levens, N. R. (1989) Am. J. Physiol. 257, G504-G510

Feinberg, A. P. and Vogelstein, B. (1983) Anal. Biochem. 132, 6-13

Force, T., Kyriakis, J. M., Avruch, J. and Bonventre, J. V. (1991) J. Biol. Chem. 266, $6650-6656$

Geisterfer, A. A. T., Peach, M. J. and Owens, G. K. (1988) Circ. Res. 62, 749-756

Gill, G. N., III, C. R. and Simonian, M. H. (1977) Proc. Natl. Acad. Sci. U.S.A. 74, $5569-5573$

Griendling, K. K., Ritterhouse, S. E., Brock, T. A., Ekstein, L. S., Gimbrone, M. A. and Alexander, R. W. (1986) J. Biol. Chem. 261, 5901-5906

Grynkiewicz, G., Poenie, M. and Tsien, R. Y. (1985) J. Biol. Chem. 260, 3440-3450

Gupta, S. K., Gallego, C. and Johnson, G. L. (1992) Mol. Biol. Cell 3, 123-128

Hausdorff, W. P. and Catt, K. J. (1988) Endocrinology 123., 2818-2826

Hepler, J. R. and Gilman, A. G. (1992) Trends Biochem. Sci. 17, 383-387

Hescheler, J., Rosenthal, W., Hinsch, K. D., Wulfern, M., Trautwein, W. and Schultz, G. (1988) EMBO J. 7, 619-624

Heslop, J. P., Blakeley, D. M., Brown, K. D., Irvine, R. F. and Berridge, M. J. (1986) Cell 47, 703-709

Higashiyama, S., Abraham, J. A., Miller, J., Fiddes, J. C. and Klagsbrun M. (1991) Science 251, 936-939

Huckle, W. R., Prokop, C. A., Dy, R. C., Herman, B. and Earp, H. S. (1990) Mol. Cell. Biol. 10, $6290-6298$

Huckle, W. R., Dy, R. C. and Earp, H. S. (1992) Proc. Natl. Acad. Sci. U.S.A. 89 $8837-8841$

Iwai, N. and Inagami, T. (1992) FEBS Lett. 298, 257-260

Iwai, N., Yamano, Y., Chaki, S., Konishi, F., Bardhan, S., Tibbetts, C., Sasaki, K., Hasegawa, M., Matsuda, Y, and Inagami, T. (1991) Biochem. Biophys. Res. Commun. 177, 299-304

Iwai, N., Inagami, T., Ohmichi, N., Nakamura, Y., Saeki, Y. and Kinoshita, M. (1992) Biochem. Biophys. Res. Commun. 188, 298-303

Kakar, S. S., Sellers, J. C., Devor, D. C., Musgrove, L. C. and Neill, J. D. (1992) Biochem. Biophys. Res. Commun. 183, 1090-1096

Landis, C. A., Masters, S. B., Spada, A., Pace, A. M., Bourne, H. R. and Vallar, L. (1989) Nature (London) 340, 692-696

Langlois, D., Begeot, M., Berthelon, M.-C., Jaillard, C. and Saez, J. M. (1992) Endocrinology 131, 2189-2195

Ledent, C., Dumont, J. E., Vassart, G. and Parmentier, M. (1992) EMBO J. 11, 537-542

Leevers, S. J. and Marshall, C. J. (1992) EMBO J. 11, 569-574

Montminy, M. (1993) Nature (London) 364, 190-191

Moolenaar, W. H. (1991) Cell Growth Diff. 2, 359-364

Murphy, T. J., Alexander, R. W., Griendling, K. K., Runge, M. S. and Bernstein, B. E. (1991) Nature (London) 351, 233-236 
Nishizuka, Y. (1986) Science 233, 305-312

Nishizuka, Y. (1992) Science 258, 607-614

Norman, J., Badie-Dezfooly, B., Nard, E. P., Kurtz, I., Schlosser, J., Chaudhari, A. and Fine, L. G. (1987) Am. J. Physiol. 253, F299-F309

Pascall, J. C., Saunders, J., Blakeley, D. M., Laurie, M. S. and Brown, K. D. (1989)

J. Endocr. 121, 501-506

Pazin, M. J. and Williams, L. T. (1992) Trends Biochem. Sci. 17, 374-378

Pfeilschifter, J., Ochsner, M., Whitebread, S. and DeGasparo, M. (1989) Biochem. J. 262. 285-291

Pobiner, B. F., Hewlett, E. L. and Garrison, J. C. (1985) J. Biol. Chem. 260, 16200-16209

Pouyssegur, J. and Seuwen, K. (1992) Annu. Rev. Physiol. 54, 195-210

Quaroni, A., Wands, J., Trelstad, R. L. and Isselbacher, K. J. (1979) J. Cell Biol. 80, 248-265

Rozengurt, E. (1986) Science 234, 161-166

Rozengurt, E. (1989) Br. Med. Bull. 45, 515-528

Rozengurt, E. (1992) Curr. Opin. Cell. Biol. 4, 161-165

Sadoshima, J. and Izumo, S. (1993a) Circ. Res. 73, 413-423

Sadoshima, J. and Izumo, S. (1993b) Circ. Res. 73, 424-438

Sandberg, K., Ji, H., Clark, A. J. L., Shapira, H. and Catt, K. J. (1992) J. Biol. Chem. 267, 9455-9458
Savage, C. R. and Cohen, S. (1972) J. Biol. Chem. 247, 7609-7611

Schlessinger, J. (1986) J. Cell Biol. 103, 2067-2072

Schlessinger, J. and Ullrich, A. (1992) Neuron 9, 383-391

Sechi, L. A., Valentin, J.P., Griffin, C. A. and Schambelan, M. (1993) Am. J. Physiol. 265, G21-G27

Simon, M. I., Strathmann, M. P. and Gautam, N. (1991) Science 252, 802-808

Sinnett-Smith, J. and Rozengurt, E. (1985) J. Cell. Physiol. 124, 81-86

Smith, R. D., Chiu, A. T., Wong, P. C., Herblin, W. F. and Timmermans, P. B. M. W. M. (1992) Annu. Rev. Pharmacol. Toxicol. 32, 135-165

Spät, A. (1988) J. Steroid Biochem. 29, 443-453

Taylor, J. B., Craig, R. K., Beale, D. and Ketterer, B. (1984) Biochem. J. 219, 223-231

Temizer, D. H., Yoshizumi, M., Perrella, M. A., Susanni, E. E., Quertermous, T. and Lee, M.-N. (1992) J. Biol. Chem. 267, 24892-24896

Thorell, J. I. and Johansson, B. G. (1971) Biochim. Biophys. Acta 251, 363-369

Timmermans, P. B., Carini, D. J., Chiu, A. T., Duncia, J. V., Price, W. A., Wells, G. J.,

Wong, P. C., Johnson, A. L. and Wexler, R. R. (1991a) Am. J. Hypertens. 4, 275S-281S Timmermans, P. B., Wong, P. C., Chiu, A. T. and Herblin, W. F. (1991b) Trends Pharmacol. Sci. 12, 55-62

Whitman, M. and Cantley, L. (1988) Biochim. Biophys. Acta 948, 327-344

Zachary, I. and Rozengurt, E. (1992) Cell 71, 891-894

Zachary, I., Sinnett-Smith, J. and Rozengurt, E. (1992) J. Biol. Chem. 267, 19031-19034

Received 21 December 1993/12 April 1994; accepted 18 April 1994 